\title{
Impact of Weather Index Insurance on Household Demand for Fertilizer in Tigray Region
}

\section{Desta Brhanu Gebrehiwot*}

\begin{abstract}
Agriculture is a risky business. And Ethiopia is one of the few countries in the world that has been ravaged by extreme drought for a number of years and stared its renaissance and development recently. According to Wondifraw Zerihun et al. 2014 on their document regarding African Economic Outlook, in 2012/13 fiscal year, Ethiopia's economy grew by $9.7 \%$, the tenth year in a row of robust growth. In 2012, Ethiopia was the twelfth fastest growing economy in the world. Average annual real GDP growth rate for the last decade was $10.9 \%$. Agriculture, which accounts for $42.7 \%$ of GDP, grew by 7.1, in order to accelerate this economic growth and minimize the weather related agricultural shocks index insurance program is being developed in Ethiopia. Hence the study aimed to investigate the impact of index insurance on farmers demand for fertilizer by using panel data of HARITA project of 2010/11 household survey in Tigray region. The study hypothesized that index insurance provision induces farmers to increase fertilizer demand which is profitable, but risky. To achieve the objectives of the study both descriptive and econometric techniques were used. The study employed random effects model with difference- in- difference estimator to see the impact of index insurance on fertilizer demand. Amount of fertilizer used was the dependent variable. Results of the random effect model showed that weather index insurance has positive significance (at 10\% level) impact on fertilizer demand. The sign of the variable indicates that insurance purchaser's fertilizer demand is more than that of non-purchasers. And purchasing index insurance leads to increase demand for fertilizer by 33 percent. Therefore, the estimated coefficient of the variable was positive sign as expected. Based on the result, the study recommends that weather index insurance program should expand in all the drought prone areas of this region, then they will become confident to adopt or increase fertilizer use, through this productive capacity and living standard, the rural society will improve over time. Finally, this study is left open for further research as index insurance is at its early stage in the study area, so there should be continuous follow up and research on this area.
\end{abstract}

Keywords: difference-in-difference, Fertilizer, HARITA, Random effect, Weather index insurance http://dx.doi.org/10.4314/ejbe.v5i1.4

*Lecturer, Department of Economics, College of Business and Economics, Mekelle University, Mobile: +251 9147604 54, Email: zdesta2003@gmail.com 
Impact of Weather Index Insurance on Demand for Fertilizer

\section{Introduction}

\subsection{Background of the study}

According to Wondifraw Zerihun et al. 2014 on their document regarding African Economic Outlook, in 2012/13 fiscal year, Ethiopia's economy grew by $9.7 \%$, the tenth year in a row of robust growth. In 2012, Ethiopia was the twelfth fastest growing economy in the world. Average annual real GDP growth rate for the last decade was $10.9 \%$. Agriculture, which accounts for $42.7 \%$ of GDP, grew by $7.1 \%$, so, this growth can be persistent if the small holder agricultural activities, which is vulnerable to whether condition related shocks is supported through adoption of weather index insurance.

Grains are the most important field crops and the chief element in the diet of most Ethiopians. The principal grains are teff ${ }^{1}$, wheat, barley, corn, sorghum and millet. However, agricultural activities in Ethiopia generally have low productivity. The agricultural sector is affected by a high level of poverty, underdeveloped infrastructure and poor entrepreneurial development.

Agricultural production is also a risky business. Farmers face a variety of price, yield and resource risks that make their incomes unstable and unpredictable from year to year. The direct results are dramatic decrease in economic development and an increase in poverty. In order to cope, some farmers have diversified crops in the case of drought or have sold cattle to repay loans or buy food (Hazell, P., et'al. 2010).

In order to solve such agricultural problems index insurance pilot is being developed in Ethiopia by Oxfam America (OA) and Swiss Re, in collaboration with IRI, the Relief Society of Tigray (REST) and other partners. Still at a relatively early stage, this project is taking a farmer-centric approach, and is

\footnotetext{
${ }^{1}$ Teff -is a type of cereal crop which is stable food crop for Ethiopians.
} 
working to integrate index insurance with other risk reduction activities such as improved agronomic practices, conservation measures, and seasonal and daily weather forecasting. Project innovations include the extension of weather insurance to communities that are technically challenging to serve, and methods that allow cash-constrained farmers to pay for premiums with their labor.

The project, which is called Horn of Africa Risk Transfer for Adaptation (HARITA), is initially targeting teff farmers in the village of Adi Ha, during 2009. In 2010 the program was expanded to additional four (Awet-bikalci, Gente, Hade-alga and Hadush-adi) treated villages found in different zones of the region. Lack of delivery channels for reaching remote and inaccessible rural customers is often a major obstacle to offering Micro insurance. To overcome this challenge, the financial institutions involved in the pilot will employ a partner-agent model. Dedebit Credit and Savings Institution (DECSI), the second largest microfinance institution in Ethiopia, will act as the insurance agent. DECSI has very extensive operations throughout Tigray, and will harness its strong community relationships and reputation to market and deliver insurance on behalf of Nyala Insurance, the primary insurance supplier. The project is also working on ways of overcoming weather data limitations. International Research Institute (IRI) has led the exploration of new techniques to enhance sparse local datasets through a combination of satellite data, rainfall simulators and statistical tools that interpolate data from stations nearby. Satellite data will also be used to improve understanding of the correlation between rain gauge data and actual losses on farms. With this information, the project may be able to reduce basis risk by answering the difficult question of what is the maximum distance between farm and rain gauge for which the rain gauge measurement of precipitation is valid. 
Impact of Weather Index Insurance on Demand for Fertilizer

The HARITA project complements Ethiopia's innovative social protection scheme, the PSNP. This reaches approximately 8 million vulnerable people, about $11 \%$ of Ethiopia's total population. The PSNP provides payments to participating households in exchange for labor to build community assets such as water harvesting structures. Such households tend to be chronically food and resource-insecure, and are likely to be unable or unwilling to pay cash for insurance premiums, despite finding risk management highly relevant to their livelihood strategies. HARITA is exploring ways to build upon the PSNP model by enabling farmers to pay insurance premiums in kind rather than in cash. Under the scheme, farmers will have the option of working a few additional days in exchange for an insurance voucher that protects them against drought (Hellmuth, M.E, et'al, 2009).

Through this insurance with PSNP labor, farmers who demand for modern agricultural inputs will be increased because the insurance creates some confidence about the compensation for expected loss from future weather condition problems. Thus they will be motivated to take risk and apply the modern inputs.

\subsection{Statement of the problem}

According to a variety of scientific studies, climate change in Ethiopia could lead to extreme temperatures, extraordinary rainfall events, and more intense and prolonged droughts and floods. These projections come as particularly bad news considering the fact that more than 85 percent of Ethiopians are engaged in smallholder, rain fed agriculture, and farms already find themselves under significant climate stress (HARITA, 2009). 
The Government of Ethiopia's agriculture policy aims to achieve rapid agricultural growth through adoption of modern inputs and commercializing smallholder agriculture. To realize this Ethiopian government introduces weather index insurance.

In 2009, index insurance contract was designed as a risk management package for farmers in the village of Adi-Ha. Farmers were creating a scalable in-kind premium payment model whereby the farmers obtained insurance through PSNP (HARITA, 2009).

Payouts occur when the amount of rainfall over an agreed range of period is below a pre determined threshold. Unlike traditional crop insurance, the insurance company does not need to visit farmers' fields to assess losses and determine payouts. Instead, it uses data from rain gauges near the farmer's field. If these data show the rainfall amount is below the threshold, the insurance has to be paid. This means that payouts can be made on time so as to reduce or avoid farmers' distress sales of assets.

This process also removes moral hazards such as the 'perverse incentives' of crop insurance, where under certain conditions farmers may actually prefer their crops to fail so that they receive a payout.

With index insurance, the payout is not linked to the crop's survival or failure, so the farmer still have an incentive to work hard and get better harvest given that the minimum amount of rain fall (Hellmuth, M.E, et'al, 2009).

In the last few years, weather index insurance has gained increasing attention as a useful tool to manage risk. Much has been said about its advantages over other traditional agricultural insurance arrangements (contracts) especially in its role to reduce transaction costs and information asymmetry. 
Nonetheless, there is still little empirical evidence of its effects on risk taking behavior and farmers' decision making (Fuchs, A. and Wolff, H. 2010). Thus, this study examines the effect of weather index insurance on farmers demand for fertilizer.

To the best of my knowledge, studies conducted so far in this field were based on experiment which shows the expected impact of index insurance if they had purchase index insurance. But such an experimental assessment could not reflect the exact impact of index insurance. This research is therefore, an attempt to fill the existing gaps on the assessment about impact of index insurance.

\subsection{Objectives of the study}

\section{General objective}

The general objective of the study was to examine the impact of weather index insurance on farmer's demand for fertilizer.

\section{The Specific objectives of the study are:}

- To assess and analyze the impact of index insurance on farmers' demand for fertilizer.

- To recommend policy options based on the findings

\subsection{Significance of the study}

Maximizing agricultural production in Ethiopia and particularly in the study region is essential to reduce poverty and ensure sustainable development. Such concerns call to investigate the underlying root causes contributing to the farmer's risk aversion behavior, which leads them to invest on less risky inputs with less return in the study area. 
Impact of Weather Index Insurance on Demand for Fertilizer

A possible solution to this problem may be providing these poor farmers with index insurance. Thus it is necessary to study whether this program has an effect on changing farmers' demand for riskier inputs, but with high return.

Hence, such studies are important for the success of huge efforts made in the area to ensure food security. Policy makers and planners can also draw lessons on designing effective strategies for further efforts in addressing food insecurity and poverty alleviation. This study will also contribute to fill a gap of knowledge in the subject. Furthermore the output of the study could be informative for development practitioners, donors and nongovernmental organizations.

\subsection{Scope of the study}

The study is conducted in five treated villages of three woredas (Raya -Azobo, Kola-Temben, and Sas'e Tsaeda-Emba) of Tigray Regional State, Ethiopia. The research design employed household survey panel data of 2010 and 2011, i.e. household base line survey which was collected in 2010 and one follow up survey data that was collected during 2011.

\subsection{Limitation of the study}

The limitations that we face during this study were shortage of time, lack of related research documents, especially empirical studies on the subject. Moreover the program is new and less known in the study area.

\subsection{Organization of the paper}

This thesis is organized into four chapters. The first chapter deals with introduction, while the research methodology is summarized in chapter two 
followed by, results and discussion in chapter three before we conclude in chapter four.

\section{Methodology of the study}

\subsection{Description of the study area}

Tigrai is located in the northern most of Ethiopia. It covers an area of approximately 54,572 square $\mathrm{kms}$. The altitude of the region varies from about 500 meters above sea level (masl) in the North-east to almost 4000 masl in the South-west. The agro-ecology of the region is broadly categorized into lowland (Kola - less than 1500 masl), midland (Woina-degua - 1500 to 2300 masl), and highland (degua - above 2300). About 53 percent of the region is lowland, 39 percent medium highland and 8 percent upper highland (BoFED, 2008 in $\mathrm{K} /$ mariam, 2010).

The study was conducted on three drought prone woredas ${ }^{2}$. Sample of purchasers and non-purchasers were taken from five treated villages (Adi-ha, Awet-bkalci, Gente, Hadealga, and Hadush-adi) found in these drought prone woredas'.

The first woreda is Kola-Temben which is found on central zone of Tigray region where, the dominant crops are teff and wheat. In this woreda there are two treated tabias ${ }^{3}$ Adi-ha and Awet-bikalsi. In late May 2009, 20\% of households in Adi-Ha signed up for a weather index insurance product for teff, a staple cereal crop. Of these households, 65\% were participants of the Productive Safety Net Program (PSNP).

\footnotetext{
${ }^{2}$ Woreda-refers to district

${ }^{3}$ Tabia- this is small administrative unit in Tigray region
}

EJBE Vol. 5 No. 1/2015 
The second is Woreda Raya-Azebo found in southern zone of Tigray The dominant crops in this woreda are sorghum ${ }^{4}$ and teff. Tere there are two treated tabias (Gentea and Hade-alga).The other is wereda Sasea-tsaedaemba found in western zone of Tigray, where the dominant crops are barley and teff. Hadush-adi is the treated tabia that is found in this woreda. Households participate in index insurance either through PSNP or by cash. Farmers that participate in PSNP purchased insurance for their dominant crop with labor, that is they have the option to work extra days beyond those required for their normal payments, but instead of earning cash or food for this additional labor, they earn an insurance certificate protecting them against rainfall risk. On the other hand richer, farmers who do not participate in PSNP are encouraged to purchase insurance with their own cash.

\subsection{Data sources and sampling method}

Household level primary data collected during 2010 and 2011 in Tigray region, Northern Ethiopia, by HARITA project using structured survey instrument was used in this study. Besides, secondary sources about the project (HARITA) and related materials were consulted. The project employed a mix of different sampling techniques. The study area and the target population were selected by purposive sampling method (i.e. drought prone woredas and PSNP participant individuals were selected purposefully), then proportional sampling method was employed to determine the sample size for each tabia. Finally respondents or households are selected by applying systematic random sampling from the sample frame of purchasers and non-purchasers.

${ }^{4}$ Sorghum -type of cereal crop

EJBE Vol. 5 No. 1/2015 
Impact of Weather Index Insurance on Demand for Fertilizer

Based on these processes 300 treated households out of 6891 treated households from five treated tabias(Adi-ha, Hadush-adi, Gentae, Hadealga, Awet-bkalci) and 100 control households from three control tabia (Menji, Werabay and Agazi) tabias were selected.

For the purpose of this study three hundred households (purchasers and NonPurchasers) from five treated villages (i.e. from Adi-ha, Hadush-adi, Gentae, Hadealga, Awet-bkalci) were taken. After some cleaning of the data, 245 households were left. These were distributed among the villages (tabias) as in the following table2.1. and table 2.2:

Table 2.1. Sample of all Treated Tabias

\begin{tabular}{|l|l|l|l|}
\hline s/no- & Tabia & Sample size & Program \\
\hline 1 & Adi-ha & 65 & Participant \\
\hline 2 & Awet-bikalci & 49 & Participant \\
\hline 3 & Gente & 55 & Participant \\
\hline 4 & Hade-alga & 58 & Participant \\
\hline 5 & Hadush-adi & 70 & Participant \\
\hline & Total & 297 & \\
\hline
\end{tabular}

Source: HARITA household survey 2010.

Table 2.2. Sample of Purchasers and Non-Purchasers from the Treated Tabias

\begin{tabular}{|l|l|l|l|l|l|l|}
\hline Village(Tabia) & Genet & $\begin{array}{l}\text { Hade- } \\
\text { alga }\end{array}$ & $\begin{array}{l}\text { Hadush- } \\
\text { adi }\end{array}$ & $\begin{array}{l}\text { Awet } \\
\text { bikalci }\end{array}$ & Adi-ha & Total \\
\hline Non-purchaser & 35 & 27 & 20 & 14 & 20 & 116 \\
\hline Purchaser & 13 & 23 & 36 & 22 & 35 & 129 \\
\hline Total & 48 & 50 & 56 & 36 & 55 & 245 \\
\hline
\end{tabular}

Source: HARITA household survey 2010. 
Impact of Weather Index Insurance on Demand for Fertilizer

The survey data contain detailed information on household characteristics (such as age and sex of the household head, schooling level of household members, etc), asset ownership, credit, non-agricultural activities, land holding, inputs, crop outputs, rented land, sharecrop land, livestock ownership, adoption of modern inputs, purchasing weather index insurance and reasons for purchasing it, etc.

\subsection{Methods of data analysis}

For the analysis of this study both descriptive and econometric techniques were used. Their respective ways of analysis are explained in detail in the next section as follows.

\subsubsection{Descriptive analysis}

In the descriptive analysis part, descriptive statics about the demographic characteristics of the sampled households and summery statistics of their modern input demand and their level of understanding about the insurance contract design were presented.

\subsubsection{Econometric analysis}

In this study econometric model that is relevant in impact analysis using panel data was employed. This is random effects model with DID estimator which is used to analyze the impact of a program using panel data.

As Pattanayak,(2009) explained, most common impact evaluation methods utilize panel data sets with two features: (i) the sample observations which are sorted into treatment and control groups, and (ii) at least one observation of the panel from before and one from after the 'treatment'. With this basic $2 \times 2$ design (before-after \& control-treatment), program impacts are estimated by 
Impact of Weather Index Insurance on Demand for Fertilizer

calculating the difference in outcomes between treatment and control groups after program implementation minus the difference in outcomes between treatment and control groups prior to the implementation. Often, we refer to this as double difference or difference-indifference (DID) estimator.

\subsubsection{Model Specification}

The aim is to provide empirical evidence about whether weather index insurance has statistically significant impact on fertilizer demand or not. For this reason two strategies: Random Effect and Difference-in-Difference model are used.

Difference-In-Difference (DID) Model: this method is widely used to evaluate the effects of policy or program changes. It is a model that allows the control group and treatment groups to have different average benefits from the treatment. This provides an estimate of the entire counterfactual distribution of outcomes that would have been experienced by the treatment group in the absence of the treatment, and likewise for the untreated group in the presence of the treatment.

The study evaluates the effect of weather index insurance or treatment on demand for modern agricultural input (fertilizer) over a population of individuals. Suppose that there are two groups indexed by treatment status $\mathrm{T}=$ 0, 1 (for simplicity, let WII=T) where 0 indicates individuals who do not receive treatment, i.e. the control group, and 1 indicates individuals who do receive treatment, i.e. the treatment group. Assume that we observe individuals in two time periods, $\mathrm{t}=0,1$ where 0 indicates a time period before the treatment group receives treatment, i.e. pre-treatment, and 1 indicates a time period after the treatment group receives treatment, i.e. post-treatment. Every 
observation is indexed by the letter $\mathrm{i}=1, \ldots \mathrm{N}$; individuals will typically have two observations each, one pre-treatment and one post-treatment.

For the sake of notation let $\mathrm{Y}_{0}^{\mathrm{T}}$ and $\mathrm{Y}^{\mathrm{T}}$ be the sample averages of the outcome for the treatment group before and after treatment, respectively, and let $\mathrm{Y}_{0}^{\mathrm{C}}$ and $\mathrm{Y}^{\mathrm{C}}{ }_{1}$ be the corresponding sample averages of the outcome for the control group. Subscripts correspond to time period and superscripts to the treatment status. The difference in difference (or "double difference") estimator is defined as the difference in average outcome in the treatment group before and after treatment minus the difference in average outcome in the control group before and after treatment: it is literally a "difference of differences."

$D I D=(Y T 1-Y T O)-(Y C 1-Y C 0)$

The main equation of the model is explained as follows:

Fertilizer $=\alpha+\beta W I I+\gamma t i+\delta(W I I . t i)+\lambda X_{i}+\varepsilon_{i}$

Where:

Fertilizer -Refers to the amount of fertilizer demanded by household $\mathrm{i}$

$\alpha$-is the constant term

$\beta$ - (treatment group specific effect) is coefficient of the dummy of purchase of Weather index insurance

$W I I$ - is the dummy variable for purchase of weather index insurance (=1if the household purchased Weather index insurance)

$t i$ - Time trend common to control and treatment groups i.e. Dummy variable ( $=1$ if the observation is after the weather index insurance program)

$\delta$ - True effect of treatment (WII)

$\lambda i$-is vector of coefficients for the explanatory variables 
$X i$ - is vector of explanatory variables (like age, sex of the household head, land holding etc)

$\varepsilon_{i}$-is the error term.

DID estimators are often implemented in a regression framework by regressing the outcome on three dummy variables - the treatment category(WII), the treatment period(ti), and an interaction variable(WII.ti) for the treatment category and period. The estimated coefficient on the interaction term measures the net change in the outcome for the treatment (program) households relative to net change in the outcome for the control households. Based on the above equation, it is possible to determine the expected values of the average outcomes as follows:

$$
\begin{aligned}
& E[Y T 0]=\alpha+\beta+\lambda \\
& E[Y c 0]=\alpha+\lambda \\
& E[Y T 1]=\alpha+\beta+\gamma+\delta+\lambda \\
& E\left[Y_{c 1} 1\right]=\alpha+\gamma+\lambda \\
& \delta D D=(E[Y T 1]-E[Y T 0])-(E[Y c 1]-E[Y c 0]) \\
& =[(\alpha+\beta+\gamma+\delta+\lambda)-(\alpha+\beta+\lambda)]-[(\alpha+\gamma+\lambda)- \\
& \alpha+\lambda \\
& =(\gamma+\delta)-(\gamma) \\
& =\boldsymbol{\delta}
\end{aligned}
$$

Random Effects Model: The other way of analyzing panel data is the Random Effects model. This approach was used to look at the net effects of index 
insurance on households demand for fertilizer. Under panel data analysis, there is formal test to choose between FEM and REM, (Hausman , 1978). The null hypothesis underlying the Hausman test is that: The FEM and REM estimators do not differ substantially. The test statistic developed by Hausman has an asymptotic $\chi 2$ distribution. If the null hypothesis is rejected, the conclusion is that REM is not appropriate and that we may be better off using FEM, in which case statistical inferences will be conditional on the $\varepsilon i$ in the sample. In REM, on the other hand, the intercept $\beta 1$ represents the mean value of all the (crosssectional) intercepts and the error component $\varepsilon i$ represents the (random) deviation of individual intercept from this mean value.

In this study the null hypothesis is accepted with 0.93 p-values. So based on this result it is appropriate to use Random Effects model. The main advantage of running Random Effects model with difference-in- difference estimator is that it enables to capture the effect of time on demand for fertilizer, since through time there may be change in fertilizer demand due to reasons other than purchasing index insurance. The equation of the Random Effects model with DID estimator is explained as follows:

$$
\text { Fertilizer }=\beta 1 i+\beta_{2} W I I+\gamma t i+\delta(W I I . t i)+\lambda X_{i}+\mathrm{ui} \ldots \ldots \ldots \ldots \ldots \ldots 1
$$

Instead of treating $\beta 1 i$ as fixed, we assume that it is a random variable with a mean value of $\beta 1$ (no subscript $i$ here). And the intercept value for an individual can be expressed as:

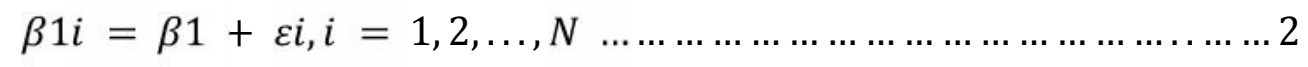

where $\varepsilon i$ is a random error term with a mean value of zero and variance of $\sigma 2 \varepsilon$ .All observations have a common mean value for the intercept $(=\beta 1)$ and the 
individual differences in the intercept values of each observation are reflected in the error term $\varepsilon i$. Substituting (2) into (1), we obtain:

$$
\begin{gathered}
\text { Fertilizer }=\beta 1+\beta_{2} W I I+\gamma t i+\delta(W I I . t i)+\lambda X_{i}+\varepsilon i+\text { ui } \ldots \ldots \ldots \ldots \ldots . . . . . .3 \\
\text { Fertilizer }=\beta 1+\beta_{2} W I I+\gamma t i+\delta(W I I . t i)+\lambda X_{i}+w i \ldots \ldots \ldots \ldots \ldots \ldots
\end{gathered}
$$

Where:

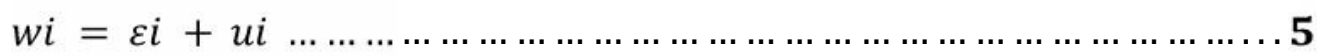

The composite error term wi consists of two components, $\varepsilon i$, which is the cross-section, or individual-specific, error component, and $u i$, which is the combined time series and cross-section error component. The term error components model derives its name because the composite error term wi consists of two (or more) error components. Notice carefully the difference between FEM and REM. In FEM each cross-sectional unit has its own (fixed) intercept value, in all $N$ such values for $N$ cross-sectional units. In REM, on the other hand, the intercept $\beta 1$ represents the mean value of all the (crosssectional) intercepts and the error component $\varepsilon i$ represents the (random) deviation of individual intercept from this mean value(Gujirat,2004).

\subsubsection{Description of Variables used in the Model}

Under this sub section dependent and independent variables that are used in this model are discussed briefly as follows:

Dependent variable: Demand for fertilizer which is continuous variable becomes the dependent variable. Thus it was regressed as of the explanatory or independent variables hypothesized below.

Independent variables: A range of demographic and socio-economic variables that are expected to influence household's demand for fertilizer are described and hypothesized below: 
Impact indictor (wiiyr): This is an interaction variable created by multiplying the treatment variable (wii) and time variable (year).The estimated coefficient on this interaction term measures the net change in the fertilizer demand for the purchasers (treatment) households relative to net change in fertilizer for the Non-purchaser (control) households.

Treatment variable ( wii): is the dummy variable for purchase of regular index insurance (=1_if the household purchased Weather index insurance and 0 otherwise).It is hypothesized to positively affect demand for fertilizer, i.e. farmers that purchase index insurance will have higher demand for fertilizer than those who do not purchase it.

Age of the household head (age): This is continuous variable and expected to have negative effect on fertilizer demand. When age of the head increases, households are expected to decrease their participation on farming activities. On the other hand, as age increases they may be experienced farmers to use fertilizer or to apply other means of maximizing productivity, such as diversifying, using manure, etc so its effect is ambiguous.

Gender of household head (gender): This is a dummy variable, which takes 1 if sex of respondent is male, 0 otherwise. Since the participation of women on farm activities is limited due to cultural impediments than males, female headed households are expected to purchase less fertilizer, thus its' effect will be negative.

Education level of household head (literate): a dummy variable which takes the value 1 if the household head is able to read and write and 0 otherwise. Households who can read and write are expected to have more demand for fertilizer as they are expected to have more exposure to farming technologies and information. Therefore it will be expected that households who are literate are better to fertilizer. 
Number of oxen holding (oxen): this is the number of oxen that the household has and it has expected positive effect on demand for modern inputs. Most of the time farmers use oxen to plough their land, so the number of oxen owned is relatively better determinant of fertilizer demand than other livestock. Price of Manure (pmanure): this is the amount of birr paid for one k.g of compost that the farmer use in his farm which is substitute product for fertilizer and is expected to influence positively demand for fertilizer. Therefore households that use more manure as a result of lower price of manure are expected to have less demand for modern inputs.

Price of fertilizer (pfer): this is the total cost paid for fertilizer divided by quantity of fertilizer purchased, and is expected to have negative effect on demand for modern inputs, i.e. the law of demand.

Own Cultivated Land (own land): this is the cultivated land size in terms of tsimad and soil type owned by the household; farmers give more focus for productivity of their own land so they increase fertilizer demand based on the soil type of the land, and hypothesized to have ambiguous effect. Since

> Walka ${ }^{5}$ and bakel soil types are considered as fertile by farmers, so farmers apply less fertilizer for this soil type. That means it has expected negative impact on fertilizer demand. While

$>$ Hutsa ${ }^{6}$ is considered as less fertile so farmers use more fertilizer for this soil type. That is it has expected positive impact on fertilizer demand.

Share crop cultivated land (shcropland): this is a continuous variable. This includes share crop in and rented land for cultivation. Households who have

\footnotetext{
${ }^{5}$ Walka-a soil type which known as vertisol

${ }^{6}$ Hutsa-soil type which is known as leptosol.
}

EJBE Vol. 5 No. 1/2015 
large size of share crop cultivated land in terms of hectare or tsemad ${ }^{7}$ may increase demand for modern inputs, or since this land is of somebody else they may not give more focus for its productivity so their demand may decrease. Therefore its expected effect is ambiguous.

Off farm income (offfarmp): this is the total income farmers generated from off own-farm activities farmers with high income may have high demand for inputs or may have less demand since they work on non agricultural activities. So its expected effect is ambiguous.

Access to credit (craccess): this is also a dummy variable which has value 1 if the house hold has access to credit 0 otherwise. Therefore, households with access to credit may have more demand for inputs.

Amount of high yielding seeds used (hyvs): This is one type of modern agricultural input which is expected to give more output if it is used simultaneously with fertilizer. So it has positive expected effect on fertilizer demand.

Price and amount of pesticide used (pesticid): This is also a type of modern agricultural input that has expected to have positive effect on fertilizer demand. Wealth status (wealth): this is perception of farmers for themselves, households that consider themselves as poor may have less demand for fertilizer so it has expected direct effect.

PSNP participation (psnp): this is dummy variable equal 1 for PSNP(productive sefti-net participants) zero otherwise .Its expected effect is ambiguous since participants may increase demand due to their access to information or may decrease demand due to the fact that participants are poor so unable to purchase modern inputs.

\footnotetext{
${ }^{7}$ Tsemad-this is traditionally used as measurement unit for agricultural land. And is approximately equal to 0.25 hectar.
}

EJBE Vol. 5 No. $1 / 2015$ 
Impact of Weather Index Insurance on Demand for Fertilizer

\section{Results and Discussion}

In this section, we present results and discussions. The first part of this chapter presents the descriptive statistics, while in the second part we discuss the econometric results of Random effects model.

\subsection{Descriptive evidences}

In this section descriptive analysis about household characteristics, households' understanding about index insurance and their level of input demand were discussed by implementing tables, charts and other calculation methods.

\section{Household head characteristics}

Household characteristics of the weather index insurance purchasers and nonpurchasers are presented in table 3.1. We found that average age of the sample household heads is 42.34 having minimum of 18 years and maximum of 75 years. The mean age of the insurance purchasers and non-purchasers is found to be 40.9 years and 43.1 years respectively. And, the $\mathrm{t}$ - test shows that there is significant difference (at 10\% level) between insurance purchaser and nonpurchaser households on the basis of the age of household head. Thus it indicates that non-purchaser households were more aged than purchasers. 
Impact of Weather Index Insurance on Demand for Fertilizer

Table 3.1: Summary of descriptive statistics (continuous variables)

Comparison of Index Insurance Purchasers and Non-purchasers

\begin{tabular}{|l|l|l|l|l|l|l|l|}
\hline & \multicolumn{3}{|c|}{ Total } & $\begin{array}{l}\text { Insurance- } \\
\text { purchasers }\end{array}$ & \multicolumn{2}{l|}{ Non-purchasers } & $\begin{array}{l}\text { Significanc } \\
\text { e of } \\
\text { difference }\end{array}$ \\
\hline $\begin{array}{l}\text { Variable } \\
\text { description }\end{array}$ & $\begin{array}{l}\text { Observat } \\
\text { ion }\end{array}$ & Mean & $\begin{array}{l}\text { Observ } \\
\text { ation }\end{array}$ & $\begin{array}{l}\text { Mea } \\
\text { n }\end{array}$ & $\begin{array}{l}\text { observ } \\
\text { ation }\end{array}$ & Mean & t-test \\
\hline $\begin{array}{l}\text { Age of } \\
\text { household head }\end{array}$ & 446 & $\begin{array}{l}42.34 \\
0\end{array}$ & 220 & $\begin{array}{l}40.9 \\
09\end{array}$ & 188 & 43.127 & $1.715^{*}$ \\
\hline $\begin{array}{l}\text { Fertilizer } \\
\text { demand }\end{array}$ & 446 & $\begin{array}{l}35.99 \\
1\end{array}$ & 220 & $\begin{array}{l}43.3 \\
63\end{array}$ & 188 & 26.803 & $2.569^{* * *}$ \\
\hline $\begin{array}{l}\text { High yielding } \\
\text { variety seeds }\end{array}$ & 446 & 6.247 & 220 & $\begin{array}{l}7.23 \\
8\end{array}$ & 188 & 5.436 & 1.185 \\
\hline Pesticide & 444 & .243 & 218 & .121 & 188 & .433 & -0.868 \\
\hline Yield (output) & 446 & $\begin{array}{l}11.31 \\
8\end{array}$ & 220 & $\begin{array}{l}9.80 \\
1\end{array}$ & 188 & 11.224 & -0.288 \\
\hline
\end{tabular}

Difference $=$ Mean (purchasers) - Mean (Non-purchasers).

*** Significance at $1 \%$ level, *Significance at $10 \%$ level

Source: Own computation based on survey data, 2010 and 2011, (NB. Missed

observations are excluded from this computation.)

Based on table 3.1. average fertilizer demand of insurance purchasers was 43 kilo grams while that of non-purchasers was 26.8 kilo gram. The difference in fertilizer demand is significant at less than $1 \%$ level. This indicates that insurance purchaser's fertilizer demand was more than non-purchasers. When we see demand of other modern inputs such as high yielding variety seeds and Pesticides by sample households, it was 6.24 kilo grams and 0.24 litters respectively.

As table 3.2, reveals 32.35 percent of the total sample households can read and write, while the remaining, which are more than half of the sample household were illiterate. When we compare educational background of insurance purchasers and non-purchasers, we found that $40.91 \%$ of the literate household 
Impact of Weather Index Insurance on Demand for Fertilizer

heads purchase insurance, while $22.34 \%$ literate households were nonpurchasers. This difference in educational background of insurance purchasers and non-purchasers is significant at less than $1 \%$ level. So this shows that more of the literate households purchase insurance relative to the non-purchasers.

The study identified that $60.78 \%$ of the sample households were headed by males, while the remaining $39.22 \%$ were female headed households. When we compare purchasers and non-purchasers, $62.73 \%$ male headed households and $37.27 \%$ female headed households were insurance purchasers. While, $58.51 \%$ male headed and $41.49 \%$ female headed households were non insurance purchasers. The chi 2 -test result shows that there is no significant difference between purchasers and non-purchasers in regard to gender.

Religion may also influence credit and fertilizer demand of households. Accordingly we found that $95.45 \%$ of the insurance purchaser households were Christians (mainly orthodox) while, Muslim community accounts the remaining percentage. On the other hand, $80.8 \%$ of the non-purchasers were Christians (mainly orthodox) while; Muslim community accounts the remaining percentage. From this it is clear that most of the sample households were Christian. But there is significant difference in religion of purchasers and non-purchasers. That is most of insurance purchasers were Christians (mainly orthodox). 
Impact of Weather Index Insurance on Demand for Fertilizer

Table 3.2: Summary of descriptive statistics (discrete variables)

Comparison of Index Insurance Purchasers and Non-purchasers

\begin{tabular}{|c|c|c|c|c|c|c|c|c|}
\hline \multirow{2}{*}{\multicolumn{2}{|c|}{ Variable description }} & \multicolumn{2}{|c|}{ Total } & \multicolumn{2}{|c|}{ Non-purchasers } & \multicolumn{2}{|c|}{ Insurance purchaser } & \multirow{2}{*}{$\begin{array}{l}\begin{array}{l}\text { Significance } \\
\text { of difference }\end{array} \\
\text { chi }^{2} \text { test* }\end{array}$} \\
\hline & & Frequency & percent & Frequency & percent & Frequency & Percent & \\
\hline \multirow{2}{*}{ Gender } & Male & 248 & 60.78 & 138 & 62.73 & 110 & 58.51 & \multirow[b]{2}{*}{0.75} \\
\hline & female & 160 & 39.22 & 82 & 37.27 & 78 & 41.49 & \\
\hline \multirow[t]{2}{*}{$\begin{array}{l}\text { Marital } \\
\text { status }\end{array}$} & $\begin{array}{l}\text { Un } \\
\text { Married }\end{array}$ & 130 & 31.86 & 60 & 31.91 & 70 & 31.82 & \multirow{2}{*}{0.00} \\
\hline & Married & 278 & 68.14 & 128 & 68.09 & 150 & 68.18 & \\
\hline \multirow[t]{2}{*}{ Education } & illiterate & 138 & 67.65 & 73 & 77.66 & 65 & 59.09 & \multirow[t]{2}{*}{$7.98 * * *$} \\
\hline & literate & 66 & 32.35 & 21 & 22.34 & 45 & 40.91 & \\
\hline \multirow[t]{2}{*}{ Religion } & Christian & 362 & 88.93 & 152 & 80.85 & 210 & 95.45 & \multirow{2}{*}{$21.61 * * *$} \\
\hline & Muslim & 46 & 11.27 & 36 & 19.15 & 10 & 4.55 & \\
\hline \multirow{2}{*}{$\begin{array}{l}\text { wealth } \\
\text { perceptio } \\
\text { n }\end{array}$} & $\begin{array}{l}\text { Not } \\
\text { Wealthy }\end{array}$ & 228 & 62.47 & 86 & 52.76 & 142 & 70.30 & \multirow{2}{*}{$11.83^{* * *}$} \\
\hline & Wealthy & 137 & 37.53 & 77 & 47.24 & 60 & 29.70 & \\
\hline \multirow{2}{*}{$\begin{array}{l}\text { Credit } \\
\text { access }\end{array}$} & No credit & 228 & 62.47 & 114 & 69.94 & 114 & 56.44 & \multirow[b]{2}{*}{$7.01 * * *$} \\
\hline & Credit & 137 & 37.53 & 49 & 30.06 & 88 & 43.56 & \\
\hline \multirow[t]{2}{*}{ PSNP } & $\begin{array}{l}\text { None } \\
\text { participant }\end{array}$ & 133 & 32.60 & 95 & 50.53 & 38 & 17.27 & \multirow{2}{*}{$51.03 * * *$} \\
\hline & Participant & 275 & 67.40 & 93 & 49.47 & 182 & 82.73 & \\
\hline
\end{tabular}

*** Significance at $1 \%$ level, *Significance at $10 \%$ level

Source: Own computation based on survey data, 2010 and 2011, (NB. Missed

observations are excluded from this computation.)

We identified also that about $82.7 \%$ of the index insurance purchasers were PSNP participants while $17.3 \%$ of the purchasers were non PSNP participants.

On the other hand $49.4 \%$ of the non purchasers were PSNP participants while $50.5 \%$ were none PSNP participants (table3.2).This indicates that almost all the insurance purchasers were PSNP participants.Poor and risk-averse households need more security in their agricultural activity relative to the rich households. This result matches with different theories regarding insurance and behavior of risk-averse households. 
Impact of Weather Index Insurance on Demand for Fertilizer

On figure 3.1 below, it is clear that in Adi-ha and Awet-bikalsi there is maximum fertilizer with small yield relative to Gente and Hadealga that adopt small fertilizer with maximum yield. This shows the effect of soil type on productivity and fertilizer demand.

In Raya Azebo there is clay or walka soil which is considered as fertile by farmers. As Mitiku, 1996, in Marc C., et al. (2000) explains black walka soils are relatively fertile, clayey soils, with high organic matter content (between 1.5 and $1.9 \%)$.

So it needs small amount of fertilizer in order to produce high yield, in addition there is larger cultivated land size than in other weredas. The reverse is true for other types of soil such as hutsa which is found in Kola-Temben. Marc C., et al (2000) states that sandy or hutsa soil type is less fertile since it has less capacity of holding water as well as less organic components.

This is because hutsa is exposed to erosion in summer season. In this area even though they apply more fertilizer their yield is not satisfactory this may be due to different reasons. Since determinant of productivity is not only fertilizer but also enough rainfall, effort of farmers and or using compost and there may be any other reasons. Therefore we can't always expect maximum output as a result of more fertilizer usage.

From this analysis, it is true that households that have fertile agricultural land haave less demand for modern agricultural inputs such as fertilizer. On the other hand, farmers that own less fertile arable land haave higher demand for fertilizer, this idea fits with different theoretical literatures. 


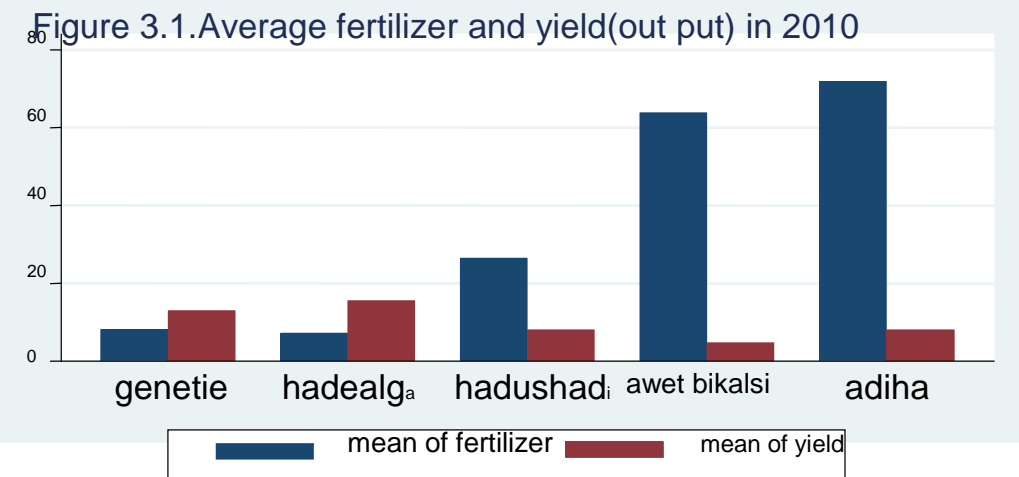

Figure 3.2, shows that demand for high yielding Variety seeds in Adi-ha $(30.38 \%)$ is more than that of Genetie, Hade-alga and Hadush-adi, which have similar demand for fertilizer, even though Awet bikalsi has less demand for high yielding Variety seeds relative to the other treated villages.

This shows that even in Genetie, Hade-alga and Hadush-adi households demand more amount of high yielding Variety seeds with less fertilizer demand. The reason behind might be fertility of their soil. Since farmers that haave fertile land need less fertilizer and more of high yielding Variety seeds to maximize production. 
Figure 3.2. Average high yielding Varity seeds used during 2010

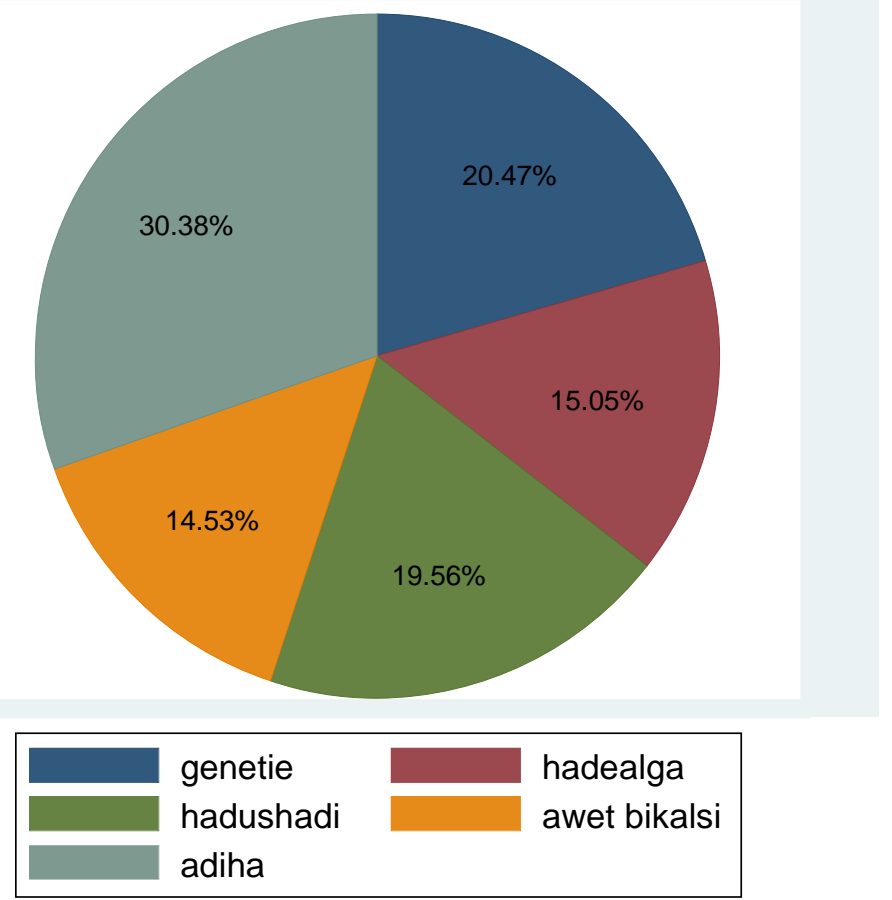

The other reason might be less productivity of the traditional crops, high yielding variety seeds could not have the same productivity with that of traditional crops, and thus farmers increase their demand for crops that give them the highest production which is obviously high yielding varieties.

In general there is high demand for high yielding Variety seeds in all sample villages. This indicates that demand for high Variety seeds does not depend on soil type (fertility) as that of demand for fertilizer rather it depends on whether condition and any other related things i.e. if there is enough rainfall their demand for high variety seeds might be increased. This is due to the reason that good weather condition plus high yielding varieties with more farmers' effort even without fertilizer leads to harvest more production. 
Impact of Weather Index Insurance on Demand for Fertilizer

\subsection{Econometric analysis}

The econometric analysis rests on comparing the difference in fertilizer purchases in the baseline and follow up surveys between farmers that purchased index insurance in follow up survey and farmers that were not. It estimates the determinants of changes in fertilizer purchases across the surveys and determines whether the provision of index insurance had any impact on the amount of fertilizer bought. This is done by using REM (random effects model with DID) estimation technique.

Table3.4. presents the DID estimates estimated with random effect. As it can be seen from the table below, the overall significance of the model is explained by wald chi2 $(18)=88.44$ which is highly significant at less than 1 percent level and in order to minimize the error term. Some continuous variables are transformed in to logarithmic form in the random effect model while in the OLS model was estimated. And almost all of the coefficients of variables have the expected signs. The result show that important variables such as price of fertilizer, PSNP participation, soil type (hutsa and walka), interaction variable (wiiyr), high yielding variety seeds, marital status, gender, educational level (literate) and perception of wealth were important variables that significantly influence households demand for fertilizer. This shows that they affect the decision of household to purchase fertilizer. This result also shows that variables like time, price of manure (which is price of substitute product), ox ownership and access to credit have positive expected sign, though they are insignificant. Below a discussion of those statistically significant variables is given:

EJBE Vol. 5 No. $1 / 2015$

Page 108 
Impact of Weather Index Insurance on Demand for Fertilizer

Impact indicator: (Interaction variable for weather index insurance and time (wiiyr))

The estimated coefficient of the interaction variable measures the pre-to-post change in fertilizer demand of the treatment (insurance purchaser) households relative to pre to post change in the fertilizer demand of the control households. The random effects model result suggests that insurance has a significant impact on fertilizer purchases. Purchasing index insurance leads to increase demand for fertilizer by 33 percent relative to non-purchasers. And this is significant at 10 percent level of significance.

The estimated coefficient of this variable was positive as expected indicating that insurance Purchasers' demand for fertilizer is more than that of NonPurchasers. Since insurance increases confidence and motivation of the farmers to take risky investments that bring more production like fertilizer which is risky if there is shortage of rainfall, but could result in more production if there is enough rainfall. In times of rainfall shortage, farmers are certain that they will be compensated, so that they can increase the use of fertilizer to maximize their production.

Kelsa, et. al., (1992) in Wassie H., and Shiferaw B., (n.d.) states that there were several occasions where the yields of cereals were increased by over $100 \%$ due to fertilizer application. Because of immediate availability of nutrients contained in inorganic fertilizer to plants, ease of application, immediately visible effect, its adoption was very fast compared to many other technologies in Ethiopia.

Previous studies on weather index insurance reveals that the program was introduced in most developing countries and its impact on modern agricultural inputs was positive. In Malawi the impact of index insurance on consumption, 
investment and on welfare was studied by Nicola (2010) and he found that Weather insurance can allow developing countries for the adoption of riskier but more-productive improved seeds such as hybrid seeds. And this leads them to increase investment on modern inputs over time because of the increase in farmers' income.

In Mexico impact of index insurance on Maize productivity was studied by Fuchs and Wolff (2010) and they also found that insurance presence in treated counties has significant and positive effects on maize productivity. This implies that there might be evidence of spillover effects in terms of increased investment or fertilizer use.

The other was the result obtained by (Hill and Viceisza, 2010) in their field experiment on the impact of weather shocks and insurance on risky investment in rural Ethiopia (Danicho Mukhere kebele in Silte zone southern Ethiopia) shows the direct relationship between index insurance and fertilizer demand. They have reported that insurance has a positive impact on fertilizer purchases. Price of fertilizer: This was continuous variable. The result of this study shows that one unit increase in price of fertilizer leads to decrease in demand for fertilizer by 1.2 percent. The variable was significant at 1 percent level of significance. The coefficient of this variable was negative as expected, showing that there is inverse relation-ship between fertilizer demand and price of fertilizer.

\section{Participation in productive safety net program (PSNP)}

This was a dummy variable ( 1 if the household participated in PSNP $^{8}, 0$ otherwise) and it was significant at $1 \%$ level of significance. The estimated

\footnotetext{
${ }^{8}$ PSNP-productive safety net program
} 
coefficient of this variable was negative, PSNP participants' demand for fertilizer decreases by 38.7 percent relative to the non-participants.

The sign of the variable indicates that PSNP participant's fertilizer demand is less than that of non- participants .Since most of the PSNP participants are poor relative to the non-participants and also have no extra time to work on different activities to generate income and invest on fertilizer.

Hutsa: This variable is farmer's own land in number of tsimads and which is hutsa soil type. So it is continuous variable. As we can see from table 4.7.below, the result of this study indicates that one percent increase in land holding of this soil type increases fertilizer demand by 21.5 percent. The variable was significant at 10 percent level of significance.

The coefficient of this variable was positive, showing that there is direct relation-ship between fertilizer demand and hutsa soil type. Farmers that have this soil type demand more fertilizer since farmers' perceive this soil type is relatively less fertile.

Marc C., et al, (2000) states that rekik soils are found on the upper portions of a toposequence, and are usually shallow. The shallow soils on the upper slope are sandier (hutsa), and have low water holding capacity. Farmers also listed rocky outcrops and crops drooping at the end of the rainy season as indicators of declining or low soil fertility. Rocky outcrops may appear as result of high levels of erosion, and they are often associated with shallow, infertile soils.

Walka: This variable is farmer's own land in number of tsimads and which is walka soil type. So it is a continuous variable. The result of this study shows that one percent increase in land holding of this soil type decreases fertilizer demand by 27.5 percent. The variable was significant at 5 percent level of 
significance. The coefficient of this variable was negative, showing that there is inverse relation-ship between fertilizer demand and walka soil type. Farmers that have this soil type demand less fertilizer. Since farmers' consider this soil type is relatively more fertile. And also Mitiku(1996) in Marc C., et al, (2000) explains that black walka soils are relatively fertile, clayey soils, with high organic matter content (between 1.5 and $1.9 \%$ ).

\section{Table 3.5: Regression results of Random Effects Model}

\begin{tabular}{|c|c|c|c|}
\hline & \multicolumn{3}{|c|}{ Dependant variable: log of fertilizer demand } \\
\hline constant & 4.383 & .711 & $0.000 * \star \star$ \\
\hline index insurance & -.036 & .169 & 0.831 \\
\hline Year(1=after insurance program) & -.031 & .169 & 0.853 \\
\hline Index insurance*year & .333 & .197 & $0.091 *$ \\
\hline Price of fertilizer & -.012 & .001 & $0.000 * \star \star$ \\
\hline Price of manure & .077 & .053 & 0.149 \\
\hline Log of oxen ownership & .064 & .115 & 0.580 \\
\hline Log of share cropland & -.034 & .080 & 0.667 \\
\hline Off farm participation & .216 & .131 & 0.101 \\
\hline Credit access & .103 & .115 & 0.369 \\
\hline Log of walka & -.275 & .140 & $0.050 *$ \\
\hline Log of hutsa & .215 & .113 & $0.057 *$ \\
\hline High yielding variety & .005 & .002 & $0.075 *$ \\
\hline PSNP participation & -.386 & .136 & $0.004 * \star \star$ \\
\hline Wealth perception & .215 & .121 & $0.074 *$ \\
\hline Log of age & -.117 & .181 & 0.515 \\
\hline Marital status & .273 & .163 & $0.094 *$ \\
\hline gender of household head & -.280 & .157 & $0.076 *$ \\
\hline Education of household head & .243 & .132 & $0.066 *$ \\
\hline Number of observation & 207 & & \\
\hline
\end{tabular}

EJBE Vol. 5 No. $1 / 2015$ 
Impact of Weather Index Insurance on Demand for Fertilizer

$\begin{array}{ll}\text { Wald chi2(18) } & 88.44 \\ \text { Prob > chi2 } & 0.000 \\ \text { sigma_u } & .338 \\ \text { sigma_e } & .610 \\ \text { rho(fraction of variance due to u_i) } & .234\end{array}$

Source: Own computation based on survey data, 2010 and 2011. *** $\mathrm{p}<0.01$, $* * \mathrm{p}<0.05, * \mathrm{p}<0.1$

High yielding variety seeds (hyvs): The other important variable is amount of high yielding variety seeds used in kilo gram. The result of this study shows that one unit increase in high variety seeds leads to increase fertilizer demand by 0.5 percent. The variable was significant at 10 percent level of significance. The coefficient of this variable was positive, showing that there is direct relation-ship between fertilizer demand and high variety seeds. Farmers that use high yielding variety seeds demand more fertilizer since they expect more output by applying more fertilizer. Both fertilizer and high yielding variety seeds are modern inputs so they can result in more production if we use both simultaneously.

Marital status: This was also dummy variable (1 if the household were married, 0 otherwise) and it was significant at $10 \%$ level of significance. The estimated coefficient of this variable was positive implying that fertilizer demand of married household heads increases by 27.4 percent relative to the non- married household heads. The sign of the variable indicates that households that are living by establishing family could participate actively different agricultural activities. Married household heads have large number of 
family members relative to the non-married household heads. So they should strengthen economically to full fill the basic needs of their family members, this strong economic capacity could be realized by actively participating in agricultural activities and by using more fertilizer to maximize production.

Wealth: This was also dummy variable ( 1 if the household considers himself as rich or middle, 0 otherwise) and it was significant at $10 \%$ level of significance. The estimated coefficient of this variable was positive, fertilizer demand of household heads that consider themselves as rich is higher by 21.6 percent relative to the household heads that perceive themselves as poor. The sign of the variable indicates that households that have good perception for themselves reflect the real wealth they own, and it is obvious that wealth and fertilizer demand have direct relationship.

Educational level (literacy): As pinpointed in various literatures, education status of the household is identified as one of the important socio-demographic factors that affect household's technology adoption. In light of this it was hypothesized that households headed by educated individuals have better chance of participating in adopting modern inputs than illiterates. As expected, the coefficient for education status was found to be positive and significant at 10 percent significance level. Result of this model shows that fertilizer demand of household heads that can read and write is higher by 24 percent than that of illiterate household heads. The sign of the variable indicates that households that can read and write have more information and awareness about different agricultural inputs, so they could distinguish 
advantage and disadvantage of such inputs simply; as a result they can increase demand of fertilizer to increase productivity.

\subsection{Model diagnosis}

In this paper the data is transformed to logarithmic form there is no problem of multicolinarity since it is checked by VIF. Hausman test (to select either Random Effect model or Fixed Effect Model) is used to select the appropriate model.

\section{Conclusion and Recommendation}

\subsection{Conclusion}

The study was conducted by using HARITA's household survey panel data of 2010/2011. It concerns with the impact of weather index insurance on fertilizer demand. Both descriptive and econometrics methods of analysis were used. Using the random effects model with difference in difference estimator we estimated the impact of index insurance on fertilizer demand in five treated villages of Tigray, Northern Ethiopia.

The result of Random Effect regression shows that, impact of weather index insurance on fertilizer demand is positive and statistically significant ( at 10 percent level). This shows that insurance Purchasers fertilizer demand is more than that of Non-Purchasers. Since insurance increases confidence and motivation of the farmers to take risky investments like fertilizer which brings more output. Such investments are risky if there is shortage of rainfall, but could result in more production if there is enough rainfall. Thus in times of rainfall shortage, farmers become certain that they will be compensated, so that they can increase the use of fertilizer to maximize their production. 
Impact of Weather Index Insurance on Demand for Fertilizer

And also ten important variables were found to be statistically significant. These are price of fertilizer, participation in PSNP, the impact indicator which is interaction variable of weather index insurance and year (wiiyr), high yielding variety seeds, households perception about their wealth status(wealth), gender of household head, educational level of household head, marital status of the household head and soil type of households own land (hutsa and walka). Previous studies on weather index insurance reveal that the program was introduced in most developing countries and its impact on modern agricultural inputs was positive. In Malawi the impact of index insurance on consumption, investment and on welfare was studied by Nicola (2010) and he found that Weather insurance can allow developing countries for the adoption of riskier but more-productive improved seeds such as hybrid seeds. And this leads them to increase investment on modern inputs over time because of the increase in farmers' income.

In Mexico, impact of index insurance on Maize productivity was studied by Fuchs and Wolff (2010) and they also found that insurance presence in treated counties has significant and positive effects on maize productivity. This implies that there might be evidence of spillover effects in terms of increased investment or fertilizer use.

The other is field experiment in rural Ethiopia (Silte zone in Southern Ethiopia) about the impact of index insurance on fertilizer demand which was studied by Hill and Viceisza (2009 and 2010) and they found that insurance has some positive effect on fertilizer purchases. Particularly for risk averse individuals who understood the insurance contract well. 
Impact of Weather Index Insurance on Demand for Fertilizer

\subsection{Recommendation}

Based on the result of the study, which shows that index insurance purchaser's fertilizer demand is higher than that of non-purchasers. So based on this, we are going to recommend the following things:

The first thing to be done is expanding weather index insurance program in all the drought prone areas of this region, households could increase fertilizer demand, through this production or economic capacity of households and living standard of the rural society in general could improve over time.

Finally, this study is left open for further research as index insurance is at its early stage, so there should be continuous follow up and research. 
Impact of Weather Index Insurance on Demand for Fertilizer

\section{References}

Alderman, H.,(2007). The Role of Index-Based Insurance in Social Protection in Low-Income Countries of Africa. Washington, D.C. , U.S.A: World Bank, working paper no_95.

Andersson, C., Mekonnen, A., and Stage, J., (2009). Impacts of the Productive Safety Net Program in Ethiopia on Livestock and Tree Holdings of Rural Households. Environment for Development (EFD) DP 09-05.

Barnett, B.J. and Mahul, O., (2007), Weather Index Insurance for Agriculture and Rural Areas in Lower Income Countries.

Dercon, S. and L. Christiaensen, (2007). Consumption Risk, Technology Adoption and Poverty Traps: Evidence from Ethiopia. World Bank Policy Research Working Paper 4257.

Fuchs, A. and Wolff, H., (2010). Drought and Retribution: Evidence from a large scale Rainfall-Indexed Insurance Program in Mexico.

Gibson, K., (2008). The future of Micro-Insurance Regulation in South Africa, Discussion Paper7.

Gujarati, D., (2004). Basic Econometrics, $4^{\text {th }}$ ed.: The McGraw-Hill Companies.

Hasanabadi, (2005). An Economic Analysis of Crop Insurance for Onion in Dharwad District. Thesis submitted to the University of Agricultural Sciences, in partial fulfillment of the requirements for the Msc. degree in Agricultural Economics. Dharwad.

Hazell, P., Anderson, J., Balzer, N., Hastrup, A., Clemmensen, U. Hess and F. Rispoli,(2010). Potential for Scale and Sustainability in Weather Index Insurance for Agriculture and Rural Livelihoods. Rome: International Fund for Agricultural Development and World Food Programme (IFAD\&WFP.)

Hellmuth, M.E., Osgood D.E., Hess U., Moorhead A. and Bhojwani H. (eds), (2009). Index insurance and climate risk: Prospects for development and disaster management. Climate and Society No. 2.International Research Institute for Climate and Society (IRI), Columbia University, New York, USA. 
Impact of Weather Index Insurance on Demand for Fertilizer

Hill,R.V. and Viceisza, A. ,(2009 and 2010) . An Experiment on the Impact of Weather Shocks and Insurance on Risky Investment Field Experiment in Ethiopia. International Food Policy Research Institute.

Horn of Africa Risk Transfer for Adaptation (HARITA), Project Overview,(2009).

Marc C., Abebe S., and Mituku H.,(2000).Farmers' knowledge of soil fertility and local management strategies in, Tigray, Ethiopia.

Mulat D.,Valerie Kelly, T.S., Jayne, Ali S., J.C. Le Vallée, and H. Chen, (1997). Agricultural Market Performance and Determinants of Fertilizer Use in Ethiopia. Ministry of Economic Development and Cooperation Addis Ababa, Ethiopia: Grain Market Research Project.

Nicola, F., (2010). The Impact of Weather Insurance on Consumption, Investment, and Welfare evidence from Malawi.

Roberts, R.A.J.(2005). Insurance of crops in developing countries, FAO. Agricultural Services Bulletin 159. Rome, Italy.

Shahidur R. Khandker, Gayatri B. Koolwal, Hussain A. Samad.(2010). Handbook on impact evaluation: Quantitative Methods and Practices. Washington DC: World Bank.

Subhrendu, k., pattanayak,(2009). Rough Guide to Impact Evaluation of Environmental and Development Programs. Kathmandu, Nepal: South Asian Network for Development and Environmental Economics (SANDEE). SANDEE working paper no_40-09.

Wassie H., and Shiferaw B.,(n.d.), Mitigation of soil acidity and fertility decline challenges For sustainable livelihood improvement: research findings From southern region of Ethiopia.

Wondifraw Zerihun, Haile Kibret, James Wakiaga, African Economic Outlook, 2014 
Impact of Weather Index Insurance on Demand for Fertilizer

\begin{tabular}{|c|c|}
\hline & $\begin{array}{c}\text { Appendices } \\
\text { Description of variables }\end{array}$ \\
\hline Variable Name & Description \\
\hline id & id of respondents \\
\hline year & dummy to time 1 for 2010 \\
\hline wii & $\begin{array}{l}\text { dummy for weather index insurance in } 2010 \text { equal } 1 \text { for } \\
\text { purchase }\end{array}$ \\
\hline tabia & Tabia of respondent \\
\hline fertilizer & Fertilizer used during 2009 \\
\hline pfer & price you pay for fertilizer in 2009 \\
\hline pcomp & price you pay for compost in 2009 \\
\hline ppest & price you pay for pesticide in 2009 \\
\hline craccess & credit access 1 for having access to \\
\hline hvs & high yielding Varity seeds used in 2009 in k.g. \\
\hline oxn & Quantity of Ox owned \\
\hline ownland & own cultivated land of the household in tsimad in 2009 \\
\hline manur & manure used during 2009 \\
\hline shcropland & irrigated and rain fed, share cropped in land \\
\hline $\begin{array}{l}\text { Wealth } \\
\text { pesticid }\end{array}$ & $\begin{array}{l}\text { Wealth status of the farmer based on his perception } \\
\text { pesticide used in } 2009 \text { in litter }\end{array}$ \\
\hline offfarmp & off farm participation dummy, 1 for participant \\
\hline yield & production in K.g \\
\hline hutsa & Hutsa/Leptosol soil type in timad \\
\hline Baekel & Baekel/Cambisol soil type in timad \\
\hline walka & Walka/Vertisol soile type in timad \\
\hline keyhhamed & Keyih/Luvisol soil type in timad \\
\hline agem 1 & Age of hh member \\
\hline gender & sex of hh head 1 for male 0 for femal \\
\hline PSNP & PSNP participation 1 for participants \\
\hline marstatus & Marital status of the hh. head 1 for married \\
\hline education & education dummy 1 for hh that can read and write \\
\hline religion & religion of the hh.head 1 for Christian \\
\hline wiiyr & interaction variable for weather index insurance and year \\
\hline landtot & own land plus share crop land in tsimad \\
\hline
\end{tabular}

EJBE Vol. 5 No. 1/2015

Page 120 
Impact of Weather Index Insurance on Demand for Fertilizer

\section{Appendix 1: Regression Result of Random Effects model with DID estimator.}

\begin{tabular}{|c|c|c|c|c|c|c|}
\hline lnfertilizer & Coef. & Std. Err. & $\mathrm{z}$ & $\mathrm{P}>|\mathrm{z}|$ & [95\% Conf.] & Interval] \\
\hline wii & -.0361061 & .1690783 & -0.21 & 0.831 & -.3674934 & .2952812 \\
\hline year | & -.0314719 & .1696673 & -0.19 & 0.853 & -.3640137 & .30107 \\
\hline wiiyr | & .3335928 & .1975153 & 1.69 & 0.091 & -.0535301 & .7207157 \\
\hline pfer | & -.0122186 & .0019627 & -6.23 & 0.000 & -.0160654 & -.0083718 \\
\hline pmanur | & .0777759 & .053929 & 1.44 & 0.149 & -.0279229 & .1834747 \\
\hline lnoxen & .0642075 & .1159907 & 0.55 & 0.580 & -.1631301 & .291545 \\
\hline Inshcropland | & -.0345894 & .0803326 & -0.43 & 0.667 & -.1920384 & .1228596 \\
\hline offfarmp | & .216304 & .1317263 & 1.64 & 0.101 & -.0418749 & .4744829 \\
\hline craccess | & .1038299 & .1156213 & 0.90 & 0.369 & -.1227837 & .3304434 \\
\hline lnwalka & -.2758209 & .1404793 & -1.96 & 0.050 & -.5511553 & -.0004864 \\
\hline Inhutsa & .2150627 & .1130212 & 1.90 & 0.057 & -.0064547 & .4365802 \\
\hline hvs | & .0050142 & .0028199 & 1.78 & 0.075 & -.0005127 & .010541 \\
\hline psnp | & -.3866891 & .1360309 & -2.84 & 0.004 & -.6533046 & -.1200735 \\
\hline wealth | & .215977 & .1210009 & 1.78 & 0.074 & -.0211804 & .4531345 \\
\hline lage | -.117950 & .1810531 & -0.65 & 0.515 & -.4728082 & .2369069 & \\
\hline marstatus | & .2738249 & .1636069 & 1.67 & 0.094 & -.0468387 & .5944885 \\
\hline gender | & -.2801165 & .1578771 & -1.77 & 0.076 & -.5895499 & .0293169 \\
\hline litrate | & .2439303 & .1327649 & 1.84 & 0.066 & -.0162841 & .5041447 \\
\hline _cons | & 4.383845 & .7117821 & 6.16 & 0.000 & 2.988778 & 5.778913 \\
\hline \multicolumn{7}{|c|}{ Number of obs 207} \\
\hline \multicolumn{7}{|c|}{ Wald chi2(18) } \\
\hline \multicolumn{4}{|c|}{ Prob > chi2 } & \multicolumn{3}{|c|}{0.0000} \\
\hline
\end{tabular}


Appendix 2. Hausman test (to select either Random Effect model or Fixed Effect Model) - hausman fe re

\begin{tabular}{|c|c|c|c|c|}
\hline & \multicolumn{2}{|c|}{ - coefficients - } & \multirow{3}{*}{$\begin{array}{c}(b-B) \\
\text { Difference }\end{array}$} & \multirow{3}{*}{$\begin{array}{c}\operatorname{sqrt}\left(\operatorname{diag}\left(V_{-} b-V_{-} B\right)\right) \\
\text { S.E. }\end{array}$} \\
\hline & (b) & (B) & & \\
\hline & & re & & \\
\hline year & 10.00717 & 7.953694 & 2.053478 & 6.667521 \\
\hline witiyr & 3.176409 & .5848875 & 2.591521 & 8.604227 \\
\hline fercost & .1225072 & .1055688 & .0169384 & .0257156 \\
\hline manurcost & .0847112 & .0573952 & .027316 & .0615151 \\
\hline pesticid & -.0863096 & .0696206 & -.1559302 & .9416559 \\
\hline hus & .2170265 & .0618134 & .1552131 & .3686713 \\
\hline oxen & 26.16438 & 12.87371 & 13.29067 & 8.036766 \\
\hline shcropland & -1.733473 & -1.145037 & -.5884355 & 1.189151 \\
\hline baekel & $-5,72047$ & -2.549189 & $-3,171281$ & 4.358641 \\
\hline walka & -3.186536 & -.2984698 & $-2,888066$ & 2.115102 \\
\hline keyih & 1.048105 & .6489878 & .3991171 & 3.726379 \\
\hline hutsa & .9967005 & 1.796248 & -.7995474 & 5.171448 \\
\hline
\end{tabular}

$b=$ consistent under Ho and Ha; obtained from xtreg $B=$ inconsistent under Ha, efficient under Ho; obtained from xtreg

Test: Ho: difference in coefficients not systematic

$$
\begin{aligned}
\operatorname{chi2}(12) & =(b-B)^{\prime}\left[\left(V_{-} b-V_{-} B\right) \wedge(-1)\right](b-B) \\
& =5.64 \\
\text { Probschi2 } & =0.9330
\end{aligned}
$$

\section{Appendix 3. Test for Multicollinarity with VIF}

\begin{tabular}{r|cc} 
vif & & \\
variable & VIF & 1 VIF \\
\hline wiiyr & 3.19 & 0.313140 \\
year & 2.72 & 0.368218 \\
gender & 2.22 & 0.450588 \\
marstatus & 2.12 & 0.471411 \\
wii & 2.09 & 0.478299 \\
oxen & 1.96 & 0.509866 \\
wealth & 1.78 & 0.563131 \\
psnp & 1.49 & 0.669442 \\
offfarmp & 1.37 & 0.728166 \\
1itrate & 1.37 & 0.730838 \\
shcropland & 1.36 & 0.736547 \\
age & 1.29 & 0.773599 \\
hutsa & 1.24 & 0.809636 \\
craccess & 1.23 & 0.814453 \\
walka & 1.19 & 0.843024 \\
hyvs & 1.12 & 0.894983 \\
pfer & 1.08 & 0.928401 \\
pmanur & 1.04 & 0.957901 \\
\hline Mean vIF & 1.66 &
\end{tabular}

EJBE Vol. 5 No. $1 / 2015$ 